MIHAELA MUDURE

\title{
ROMANIAN ENGLISH STUDIES SPECIALISTS AND NATIONAL LITERARY HISTORY
}

The present paper is divided into two parts. The former part analyses the relationship between English Studies specialists from Romania and the English cultures they serve through their activity. In other words, we look from Romania to the Anglophone cultures as a study object. The latter part of this study changes the perspective, namely we deal with the way in which the reception of English literature is or should be integrated into the national literary histories.

The ambition of any literary historian, his opera magna, is a literary history. The test of supreme complexity is writing a literary history, preferably from the beginning of a literature to its contemporaneous stage. It is a test of impressive difficulty because it supposes a lot of knowledge and the perusal of an amazing number of studies. Taking into account the prestige of literary history, we wonder: how many literary histories of Britain by Romanian scholars are there?

The catalogues of the most important Romanian libraries include several books whose titles contain the syntagma "History of English literature". Chronologically speaking, the History authored by Anixt and translated by Leon Leviţchi and Ion Preda in 1961 is to be mentioned. Anixt's History was a research model imposed but also necessary at that time and at that stage of development of the English Studies in Romania. After World War II, Romania entered the orbit of the Soviet Union. Without losing its political independence de facto, Romania got into a state of semi-colonial dependence from the Soviet Union. Economically, Romania was deprived of many of its resources under the guise of the war debts obligation. The war debts were the exaggerated ${ }^{1}$ costs of the damages Romanian army had caused the Soviet Union during World War II. Culturally, the newly installed political authorities supported a real cult of Soviet culture and science. Everything had been invented by Soviet minds. Consequently, English Studies also had to reinvent themselves under the Soviet orbit. The result of this policy was the translation of the History of English Literature by Anixt. The unsigned paratext of the History contains a tribute to the Soviet culture which respects "the works of the great masters from other countries"2. The Soviet scholar Anixt wrote his work together

\footnotetext{
${ }^{1}$ Vae victis!

${ }^{2}$ Alexandr Abramovic Anixt, Istoria literaturii engleze [History of English Literature]. Translated by Leon Leviţ̧chi and Ion Preda. Bucharest, Editura Ştiinţifică, 1961, p. 6: „Cultura sovietică, pătrunsă de spiritul internaționalismului, se caracterizează prin respect față de cuceririle culturii, ale știintei și ale artei altor popoare. Însufleţiţi de o legitimă mândrie pentru contribuţia adusă de literatura noastră la tezaurul artei universale, noi dăm preţuirea cuvenită operelor marilor maeştri din celălalte ţări”.
} 
with another colleague M.D. Zabludovski who died on the front and the book is dedicated to his memory. Anixt's History is not without merits. The author has detailed knowledge of the literary texts, the historical context of each work is amply and competently presented according to the type of Marxist approach cultivated during that time. Unfortunately, the political criterion is excessively used. Critics and writers are divided into two groups: progressive and decadent. A typical representative of decadentism is James Joyce ${ }^{3}$. Other decadents are D. H. Lawrence, T.S. Eliot or Aldous Huxley. For a long time and in the absence of any possibilities to get access to English and American sources, Anixt's History was a main source of information for English Studies students, teachers, even scholars. A scholarly proof of what it meant to be in the "socialist camp"!

We can criticize the imposition of Anixt's History as a sort of Bible of English Studies in Romania. Neither can one forget that the English Studies specialists from Romania have not been able yet to give a History of English or American literature from beginnings to contemporary evolutions. In 1961 Valeria Alcalay dared challenge Anixt with a History that covers only the periods safe from the ideological point of view. The farther the literary historian was from the contemporary literature, the safer he was. No wonder, therefore, that Alcalay preferred to deal with the period from the beginning of English literature to Shakespeare. Her book was a study dedicated to the students in the English Departments of the country. A huge gap followed until 1978 when Aurel Curtui published another History. This one was from Ben Jonson to Jonathan Swift and it was also dedicated to the English Studies students. This study was incorporated into the History of English Literature: From the Beginning to Preromanticism signed by Nicolae (sic) Creţiu ${ }^{4}$, Nicolescu, Curtui and published in 1991. It is an ominous transformation because in 1999 Corneliu Nicolescu recycled the whole text under the title A History of English Literature: From the Anglo-Saxons to Restauration and under his signature (forgetting to add the other authors). The same text was re-published by Nicolescu under the same title in 2000 and 2002, in some kind of editorial frenzy.

A well documented History of English Literature covering the period from Walter Pater to Wells gave Virgil Stanciu in 1981. The intention of continuity is suggested by the indication from the title that this is just Volume I. Unfortunately, Stanciu, well versed translator, stopped here. Translation became his favourite scholarly activity. Another version of this History changes the paratext from the writers' names (Pater and Welsh) to the crossroads between the nineteenth and the twentieth centuries. Ileana Galea published, in 1985, another History, which, in fact, covered only the Victorian Novel. Both Stanciu and Galea revisited their texts after 1990 and published new versions benefitting from the post-1990 freedom of

\footnotetext{
${ }^{3}$ Ibidem, p. 43.

${ }^{4}$ Actually, the author's name is Ioan Creţiu.
} 
information. Galea published Victorianism and Literature in 1996. Stanciu's The Transition to Modernism in English Literature came out in 2007.

The targeted readership of all these Histories were the students of the English Departments from Romania. Consequently, thorough documentation and exact, correct information are considered to be extremely important. Authors are not interested in offering challenging, original interpretations of the literary texts. These are classical, disciplined Histories whose main purpose is informative. The difficulties of accessing international bibliography led to the appearance of these partial Histories which were vital in the training of the students from the English Departments. After 2000 the necessities of the newly founded or recently developed English Departments all over Romania led to the publication of other didactic Histories of the type mentioned above. In 2004 Procopie Clonţea published a History from the beginnings to Shakespeare, which was followed, in 2005, by another edition going from the beginnings of English literary history to the Restoration. In 2008 Arleen Ionescu published another History (textbook) going from the Middle Ages to the Renaissance.

The Romanian scholar who was the closest to the ideal of covering all the historical unfolding of English Literature from the beginnings to contemporaneity was Leon Leviţchi. It was he who published a first volume of The History of English and American literature at Dacia Publishing House, in 1985. The intention of a larger project was evident.

In the Foreword to this first volume, Levitchi says: "I thought it to be our duty to give quotations from the criticism by Romanian Amglicists and scholars. The statistics of their contributions is modest, but the substance of many of them is not below what we can find elsewhere"s. Ion Barbu is quoted in connection with Roger Bacon $^{6}$, Mihnea Gheorghiu is mentioned for his study Scene din viaţa lui Shakespeare ${ }^{7}$, Ion Marin Sadoveanu for his analysis of A Midsummer Night's Dream $^{8}$, Alexandru Olaru is remembered for his psychiatric study on Shakespeare? A quotation from an article published by Eminescu in Familia, issue 8/1870, "Shakespeare must not be read, but studied" ", is used by Leviţchi in order to give more credibility to his discourse. As the year 1985 when he published his History was also one of the years of blatant and aggressive communist nationalism in the Romanian public life, this reference could also be a cautious gesture. Quoting

\footnotetext{
${ }^{5}$ Leon Levițchi, Istoria literaturii engleze \& americane [History of English \& American Literature], vol. I, Cluj-Napoca, Dacia, 1985, p. 13: “am considerat ca o datorie a noastră să reproducem şi citate din critica angliştilor şi oamenilor de cultură români. Modestă este statistica luărilor lor de cuvânt; dar substanţa multora nu e cu nimic mai prejos decât cea pe care o aflăm aiurea".

${ }^{6}$ Ibidem, p. 48.

${ }^{7}$ Ibidem, p. 193.

${ }^{8}$ Ibidem, p. 195.

${ }^{9}$ Ibidem, p. 183

${ }^{10}$ Ibidem, p. 237: "Shakespeare nu trebuie cetit, ci studiat"
} 
Eminescu you could not be accused of cosmopolitanism. The memory of the Stalinist campaign against cosmopolitanism was not dead yet. Other Romanian scholars used in order to give a more serious foundation to Leviţchi's scholarly discourse are: Adrian Marino in defining the Renaissance, Petre Solomon for his monograph on Milton, and Ioan (Iancu) Botez ${ }^{11}$ in reference to John Dryden.

The Aesopic discourse was a characteristic of the time. From this point of view, one cannot miss a very interesting remark quoted by Leviţchi from Ion Omescu who referred to Hamlet and Cymbeline in the following terms: "Denmark is a prison, prisons are man, the matrimonial relationship, the feudal state, the universe" $(224)^{12}$. The reference to the carceral universe was not without a certain echo in the mind of the Romanian reader who had just escaped from the terror of the Stalinist Gulag.

Omissions of Romanian anglicists in the scholarly foundation of Leviţchi's History are also significant. Dragoş Protopopescu and Haig Acterian censored by the Communist regime because of their far-right political ideas are also censored by Leviţchi. One can understand these absences thinking of the political and historical context. Less understandable is the omission of Zoe DumitrescuBuşulenga, the author of a very good study on Chaucer, and a scholar who was accepted by the ideological authorities of the time.

Some kind of continuity with the previous Soviet bound scholarship that used to be compulsory in Romania in the 1950's is ensured by quoting Anixt ${ }^{13}$ although Leviţchi's History was published in 1985. The text may have been drafted earlier. In any case, besides Anixt, other Soviet scholars, Alexeev, Kozînţev, Amonsova, and Morozov ${ }^{14}$ are referenced. They offer a kind of good scholarship backup. A huge change is the overwhelming presence of British and American scholars who constitute most of the references in this 1985 book. It is clear that that some members of the then Romanian intellectual elites were allowed to travel abroad and get scientific information from beyond the Iron Curtain.

Most of the quotations from the literary texts analysed in the History are by Leviţchi himself. Still, occasionally, other translators' work is also used: Şt. O. Iosif, Ion Vinea, Dan Duţescu, or Teodor Boşca.

Volume II of Leviţchi's History goes from 1700 up to Romanticism and it was published under the signature of Leon Leviţchi, Sever Trifu, and Veronica Focşăneanu, after the death of the main author (1991), in 1994. This History incorporates Jane Austen into the chapter dedicated to Romanticism without too much arguments in this respect. Volume II will be republished under the signature

\footnotetext{
${ }^{11}$ Ioan Botez (1871-1947) introduced the English language into the Romanian middle and high schools and taught English at the University of Iaşi.

${ }^{12}$ Leon Leviţchi, Istoria literaturii engleze \& americane, p. 224: "Danemarca este o închisoare, închisori sunt omul, relaţia matrimonială, statul feudal, universul".

${ }^{13}$ Ibidem, p. 59.

${ }^{14}$ Ibidem, p. 56, 101, 147, 187.
} 
of the same trio by All Publishing House in 1998. The often republishing of the Histories of English literature by Romanian scholars shows that there was a need, probably even a hunger for such studies. Unfortunately, till now Romanian anglicists have only offered partial histories of English literature ${ }^{15}$. The original voice of Romanian anglicists was almost completely stifled during the early decades of Communist dictatorship but it is high time we regained our own voice and avoid the inverse complexes: neglecting Romanian scholarship and relying our studies only on international sources.

If we look around at our post-communist neighbours, we see that in 1966 Piotr Graff translated George Sampson's History of English Literature into Polish. He offered the general as well as the specialized public from Poland access to a genuine source of British scholarship. In-between sources of Soviet origin were avoided. The Czech Nenadál Radoslav already gave A Brief Outline of English and American Literature in 1958 and the Slovak Eva Kolárová published a similar work in 1974. In Poland, Andrzej Kopcewicz and Marta Sienicka published a complete history of American Literature in 1982-1983 and Liliana Sikorska gave An Outline History of English Literature in 2002. All these works are complete overviews of English or American literature. How can one explain these different cultures of English in the communist and post-communist space ${ }^{16}$ ? How can one explain the different practices of adoption and adaptation of English in countries which share a twentieth-century commonality: the imposition of the Communist regime? Does the answer lies in the different levels of aggressiveness of the Communist regimes? Was censorship more lenient in some Communist countries than in others? Or do we have here the well-known Romanian complex of the work forever begun and never finalized? Possibly all these factors influenced, to a certain extent, attitudes, private as well as personal policies in English Studies from Romania: a certain hesitation of Romanian anglicists to get rid of the imposed Soviet model and also to finalize such a challenging work as a complete history of English literature or of any other Anglophone literature.

The second part of this paper deals with the strategies to integrate the reception of foreign literatures (particularly the Anglophone ones) into national literary histories. In other words, the Damrosch from What Is World Literature $?^{17}$ is not without predecessors. Huck Gutman published, in 1991, a collection of articles entitled As Others Read Us: International Perspectives on American Literature. In the introductory study, Gutman recommended the integration of the studies by the

\footnotetext{
15 Romanian Americanists are even more indebted to their readership than their colleagues, the Romanian Anglicists. Up to now there is no History of American literature by a Romanian scholar. This is also due to the later reception of American literature in Romanian culture.

${ }^{16}$ See Adriana Neagu, "The Cultures of English: Anglophone Sensibility, Regional Confluences and the Romanian Difference", American, British and Canadian Studies, 2010, 14, pp. 59-75.

${ }^{17}$ David Damrosch, What Is World Literature?, Princeton, Princeton University Press, 2013.
} 
Americanists from abroad into the history of American literature. This de-centred perspective has several advantages, according to Gutman: firstly, "enriching perspectives, greater self-definition for all concerned"18; secondly, such an approach "also testifies to the ways in which cultures in general interact with one another, and the importance of national history, ideology, indigenous social structure, in transcultural interaction" 19 . Consequently, Gutman conceptualizes the metatext about American literature as a historical and international research in the sense developed by Pascale Casanova in her 1999 book La République Mondiale des Lettres, which focuses on the Francophone space ${ }^{20}$. Still her conclusions can be extrapolated, or at least taken into account when analysing other cultural spaces as well.

In 2015 Suman Gupta analysed in a seminal essay the "global penetrations and pluralistic formation" 21 of the English Studies. Translations in and from English are an important segment of English Studies scholarship. Anglicists should abandon the centralized perspective on English and also consider the condition of English as a cultural import and the significance of this import. Therefore, research should be made on the "[v]various narratives of the emergence, development, and contemporary condition of English Studies"22. Two examples can be relevant for this approach. The first Romanian translation of Jane Austen ${ }^{23}$ - Gheorghe Nenişor's version of Pride and Prejudice - was published in 1943 while Romania was at war with Great Britain. Was this cultural act a hidden manifestation of sympathy with the enemies of the alliance Romania belonged to in $1943^{24}$ ? Not impossible. The paratext clearly shows the translator's sympathy for everything that is British. An even more powerful example is that of Roman Dyboski, author of Wielcy pisarze amerykanscy [Great American Writers]. He went into hiding in the building just opposite the Warsaw headquarters of the Gestapo. It was during this period of isolation that he wrote this collection of essays on great American writers. An admirable gesture of cultural defiance to dictatorship! In 1940, the Nazis started the so-called "Aktion AB" directed against the Polish intelligentsia, as a result of which many intellectuals were either shot, or sent to concentration camps to die there. Roman Dyboski went into hiding in order to avoid the fate of many of his colleagues who had been sent to the camp of Sachsenhausen already in October 1939.

\footnotetext{
${ }^{18}$ Hugh Gutman (ed.), As Others Read Us: International Perspectives on American Literature. Amherst, University of Massachussetts Press, 1991, p. 16.

${ }^{19}$ Ibidem, p. 16.

${ }^{20}$ Pascale Casanova, La république mondiale des lettres., Paris, Seuil, 1999.

${ }^{21}$ Suman Gupta, Philology and Global English Studies: Retracings, New York, Palgrave Macmillan, 2015.

${ }^{22}$ Ibidem, p. 9.

${ }^{23}$ Surorile Bennet, the first Romanian version of Pride and Prejudice.

${ }^{24}$ In 1943 Romania was an ally of Nazi Germany.
} 
In his admirable meditation on what is world literature David Damrosch pleads for the inclusion of translations and their avatars into the comparative study of literatures. Attention should be paid to "tracing what is lost and what is gained in translation, looking at the international shifts of language, era, region, religion, social status and literary context that a work can incur as it moves from its point of origin out into a new cultural sphere"25. In Romanian literature translators and translations (both ways, meaning from and into Romanian) have been included in reference books. The dictionary compiled by Zaciu, Sasu and Papahagi, published in 2000, the dictionary compiled by Aurel Zaciu, published in 2006, or the dictionaries of Romanian Literature published under the auspices of the Romanian Academy in 1979 or between 2004-2009 - the latter under the authority of Eugen Simion - they all include entries on translators and translations. More than that, it is also under the auspices of the Romanian Academy that chronological dictionaries of the Romanian novel (from the beginning up to 2000) and of the novel translated into Romanian (from the beginning up to 2000) were published. The lexicographic policy was the same: translations were included ${ }^{26}$. Romanian literature has always paid attention to its reception abroad and to what it should receive from abroad in order to catch up and not be left behind. Its marginality from the great centres of literary and political power was both a spur and a backlash.

The inclusion of literary translations into the courses of Anglophone literary histories can also be very beneficial in surpassing this painful duality. First of all, sequences about the reception of certain English literary works in Romanian culture will include the new information into the system of literary knowledge that the student already has from high school. Or this system that precedes the University is based upon the national literary histories. For instance, the study of Jonathan Swift's work proper can be enriched by the study of his reception in Romanian culture. How can one explain the transition from an infantilized Swift in his nineteenth century Romanian reception to a very different Swift in the twentieth

\footnotetext{
${ }^{25}$ David Damrosch, What Is World Literature?, p. 34.

${ }^{26}$ However, this valorization of translation considered to be part of the national literary project coexists with a different attitude. The Romanian Academy has never admitted a specialist in foreign cultures among its members. Dan Grigorescu, eminent Anglicist and Americanist, was not a member of the Philology Section. The Writers' Union awards prizes for translations but there is no clear policy in the definition of the translation. Most of the time it was translations from foreign languages into Romanian that were awarded. But there were also some occasions when translations of Romanian books into English were awarded by the branches of the Union. Last but not least, literary translators themselves can belong to several professional guilds: the Writers' Union, the Association of Translators from Romania or the Association of Literary Translators from Romania. This indicates a democratic environment but also some confusion about one's professional identification. The accreditation committees of the Ministry of National Education do not differentiate between specialists in Romanian literature and foreign literatures. They are all included into the Philology committee, which can prevent a very correct evaluation of doctoral or habilitation theses.
} 
century? Ion Eremia offered us an anti-totalitarian Gulliver in his distopia Guliiver în Ţara Minciunilor, while in Călătorie în Capricia, Mircea Opriţa obliges Gulliver to confront Romanian post-communism in a savoury story. Dragos Protopopescu wrote a emminent doctoral thesis on Congreve under the guidance of the well-known literary historian Émile Legouis and defended it at Sorbonne during the inter-war period. Protopopescu's study is significant for the appearance of a Romanian elite well informed, sophisticated and transnational in its aims and achievements. The enthusiastc reception of Milton by the 1848 literary generation can be relevant for an inside-out understanding of the republican and the revolutionary ideals of the Romanian elite at mid-nineteenth century. How can we explain the belated reception of a writer such as Laurence Sterne in Romanian culture although he was very popular in Russian culture (Orthodox and East Europeans like the Romanians) or in French culture (which was a conduit for many English writers in their navigation toward Romanian territories)? And such queries could go on...

In conclusion, we are convinced that the divisive difference national/international can no longer work in today's global world as it functioned during the nineteenth and the twentieth century. On the one hand, Romanian have always been more receptive to the ideas of reception and travelling texts than their colleagues from the centres of literary power. On the other hand, there is a sense of protectiveness from everything that represents foreign-ness which comes from the minoring status of Romanian culture, a status that has been internalized for a long time. Looking at the English language and the cultures it represents as a mode of cultural production overpassing these antynomical attitudes can help both insiders and outsiders of Romanian culture and language articulate the specificity of Romanian culture in a new way.

\section{BIBLIOGRAPHY}

\footnotetext{
***. Dicţionarul cronologic al romanului românesc (1990-2000) [The Chronological Dictionary of the Romanian Novel (1990-2000)], Bucharest, Editura Academiei Române, 2011.

***. Dicţionarul cronologic al romanului românesc de la origini până la 1989 [The Chronological Dictionary of the Romanian Novel from its Origins to 1989], Bucharest, Editura Academiei Române, 2004.

***. Dicţionarul cronologic al romanului tradus în România 1990-2000 [The Chronological Dictionary of the Translated Novels in Romania 1990-2000], Cluj-Napoca, 2017. http://instpuscariu.ro/dcrt4.pdf

***. Dicţionarul cronologic al romanului tradus în România de la origini până la 1989 [The Chronological Dictionary of the Translated Novels in Romania, from its Origins to 1989], Bucharest, Editura Academiei Române, 2005.

***. Dicţionarul literaturii române de la origini până la 1900 [Dictionary of the Romanian Literature from its Origins to 1900], Bucharest, Editura Academiei Republicii Socialiste România, 1979.
} 
ALCALAY, Valeria, Curs de istoria literaturii engleze de la începuturile ei până la William Shakespeare [Lectures on the History of English Literature from its Origins to William Shakespeare], Bucharest, Editura Didactică şi Pedagogică, 1961.

ANIXT, Alexandr Abramovic, Istoria literaturii engleze [History of English Literature]. Translated by Leon Leviţchi and Ion Preda, Bucharest, Editura Ştiinţifică, 1961.

AUSTEN, Jane, Surorile Bennet. Translated and prefaced by Gheorghe Nenişor, Bucharest, Socec, 1943.

CASANOVA, Pascale, La république mondiale des lettres, Paris, Seuil, 1999.

CLONŢEA, Procopie P., A History of English Literature: From the Beginnings to the Restoration, Piteşti, Editura Universităţii Piteşti, 2005.

CLONȚEA, Procopie P., A History of English Literature: From the Beginnings to William Shakespeare, Piteşti, Editura Universităţii Piteşti, 2004.

CREȚIU, Nicolae, CURTUI, Aurel, NICOLESCU, Corneliu, A History of English Literature: From the Beginnings to Preromanticism, Cluj-Napoca, Universitatea Babes-Bolyai, 1991.

CURTUI, Aurel, History of English Literature: From Jonson to Swift, Cluj-Napoca, Universitatea Babes-Bolyai, 1978.

DAMROSCH, David, What Is World Literature?, Princeton, Princeton University Press, 2013.

DUMITRESCU-BUŞULENGA, Zoe, "Prefaţă" ["Preface"], in Geoffrey Chaucer, Povestirile din Canterbury. Translated by Dan Duţescu, Bucharest, Editura pentru Literatură Universală, 1964, pp. I-XXV.

DYBOSKI, Roman, Wielcy pisarze amerykańscy [Great American Writers], Warszawa, PAX, 1958.

GALEA, Ileana, A History of English Literature: The Victorian Novel, Cluj-Napoca, Universitatea Babes-Bolyai, 1985

GALEA, Ileana, Victorianism and Literature, Cluj-Napoca, Dacia, 1996.

GUPTA, Suman, Philology and Global English Studies, New York, Palgrave Macmillan, 2015.

GUTMAN, Hugh (ed.), As Others Read Us: International Perspectives on American Literature, Amherst, University of Massachussetts Press, 1991.

IONESCU, Arleen, A History of English Literature: The Middle Ages and the Renaissance, Ploieşti, Editura Universităţii "Petrol şi Gaze", 2008

KOPCEWICZ, Andrzej and SIENICKA, Marta, Historia literatury Stanów Zjednoczonych w zarysie. Wiek XX [Outline History of US Literature. $20^{\text {th }}$ Century], Warszawa, PWN, 1982.

KOPCEWICZ, Andrzej and SIENICKA, Marta, Literatura amerykańska do 1900 roku w zarysie" [Outline History of American Literature till 1900], Warszawa, PWN, 1983

LEVIȚCHI, Leon, Istoria literaturii engleze \& americane [History of English \& American Literature], vol. I., Cluj-Napoca, Dacia, 1985.

LEVIŢCHI, Leon, TRIFU, Sever, FOCŞĂNEANU, Veronica, Istoria literaturii engleze \& americane [History of English \& American Literature], vol. II, Cluj-Napoca, Dacia, 1994.

LEVIŢCHI, Leon, TRIFU, Sever, FOCŞĂNEANU, Veronica, Istoria literaturii engleze \& americane [History of English \& American Literature], vol. II, Bucharest, Editura All, 1998.

NEAGU, Adriana, "The Cultures of English: Anglophone Sensibility, Regional Confluences and the Romanian Difference", American, British and Canadian Studies, 2010, 14, pp. 59-75.

NICOLESCU, Corneliu, A History of English Literature: From the Anglo-Saxons to Restauration, Cluj-Napoca, Motiv, 1999.

NICOLESCU, Corneliu, A History of English Literature: From the Anglo-Saxons to Restauration, Cluj-Napoca, Motiv, 2000.

NICOLESCU, Corneliu, A History of English Literature: From the Anglo-Saxons to Restauration, Cluj-Napoca, Motiv, 1999, 2002.

SAMPSON, George, Historia literaturi angielskie w zarysie: podręcznik, Warszawa, Państwowe Wydawnictwo Naukowe, 1966.

SASU, Aurel, Dicţionarul biografic al scriitorilor români [The Biographical Dictionary of Romanian Writers], Piteşti, Editura Paralela 45, 2006.

SIKORSKA, Liliana, An Outline History of English Literature, Poznan, Wydaw. Poznańskie, 2002. 
SIMION, Eugen (ed.), Dicţionarul general al literaturii române [General Dictionary of Romanian Literature], Bucharest, Universul Enciclopedic, 2004-2009.

STANCIU, Virgil, A History of English Literature: From Pater to Wells, vol. I, Cluj-Napoca, Universitatea Babes-Bolyai, 1981.

STANCIU, Virgil, A History of English Literature: The Last Decades of the 19th Century and the 20th Century, Cluj-Napoca, Universitatea Babes-Bolyai, 1981.

STANCIU, Virgil, The Transition to Modernism in English Literature, Cluj-Napoca, Limes, 2007.

ZACIU, Mircea, PAPAHAGI, Marian, SASU, Aurel, Dicţionarul esenţial al scriitorilor români [The Essential Dictionary of Romanian Writers], Bucharest, Albatros, 2000.

\section{THE ROMANIAN ENGLISH STUDIES SPECIALISTS AND NATIONAL LITERARY HISTORY \\ (Abstract)}

The study analyses Romanian specialists' attempts to compile histories of Anglophone literatures. Special attention is paid to Leon Leviţchi's contribution to the Romanian historiography of English Literature. The second part of the paper deals with the strategies to integrate the reception of foreign literatures (particularly Anglophone ones) into national literary histories, emphasizing the fact that David Damrosch has some valuable predecessors among the authors of Romanian literature dictionaries.

Keywords: English literature, foreign literatures, Leon Levițchi, Romanian historiography, translation.

\section{ANGLIȘTII ROMÂNI ȘI ISTORIA LITERARĂ NAȚIONALĂ (Rezumat)}

Studiul analizează demersurile cercetătorilor literari români de a realiza istorii ale literaturilor anglofone. $\mathrm{O}$ atenție specială e acordată contribuțiilor istoriografice despre literatura engleză semnate de Leon Levițchi. A doua parte a lucrării abordează strategiile de integrare a receptării literaturilor străine (în special, a celor anglofone) în istoriile literare naționale, accentuând că David Damrosch are câțiva precursori însemnați printre autorii dicționarelor literare românești.

Cuvinte-cheie: literatură engleză, literaturi străine, Leon Levițchi, istoriografie românească, traducere. 